\title{
RECONSTUCTION OF THE HISTORICAL BUILDING FOKSAL 13 AND 15 IN WARSAW
}

\author{
TOMÁš ̌̌RDINA
}

\begin{abstract}
FG CONSULT, s.r. o., K jezu 1937/1, 14300 Prague, Czech Republic
correspondence: redina@fgc.cz
\end{abstract}

\begin{abstract}
We were asked to design geotechnical structures to enable reconstruction of historical buildings. Buildings have to meet current standards so load bearing capacity had to be increased and underground garages can be built. A description of the securing construction pit is described below as well as the design of the deep foundation. The construction pit was secured by jet-grouting columns with struts and soil nails. Parts of the walls were underpinned by micropile trestles. Jet-grouting columns were also used for the deep foundation of existing walls.
\end{abstract}

KEYWORDS: Jet grouting, historical buildings, underground garages, shoring.

\section{INTRODUCTION AND HistoriCAL REVIEW}

The block of flats on Foksal Street was built in the late $19^{\text {th }}$ century and, as one of the few buildings in Warsaw, it survived the Second World War. After the war it was initially used as rented housing, but nobody invested in their maintenance because it was intended that they be demolished due to the construction of a tram line. In the 1990s residents were evicted because of the threat to health and life. A major rebuilding began in 2016. The development of the whole project was characterized by the investor's effort to find the easiest solution, while on the other hand the requirements of heritage conservation institutions was to protect historically valuable buildings in the centre of Warsaw. The investor wanted to build for luxury living and a necessary condition for this standard was the obligation to add underground garages to the floor plans of both buildings. The compromise solution eventually became an approved version involving the demolition of the rear and middle wings of Foksal 15. In place of the demolished wings, underground garages were built, while new wings of the same extent and the same facade construction were also built. The state of the building before and after reconstruction is shown in Figure 1 .

\section{GeOlOGiCAL AND Hydrogeological Provisions}

Below a layer of artificial backfill with thicknesses of $1-2.3 \mathrm{~m}$, pleistocene formations are found. These formations reach a depth of $12-15 \mathrm{~m}$ below the terrain and are formed with sandy clay, with a depth of consistency varying from solid to firm in the lower parts, and then very firm. Locally, the layers of clay were lined with fluvioglacial sand lenses with an $\mathrm{Id}=0.8-1.0$. All sediments are heavily disturbed glaciotectonically.

In a basic survey (April 2016), underground water was found at depths of more than $15 \mathrm{~m}$ under the ter-
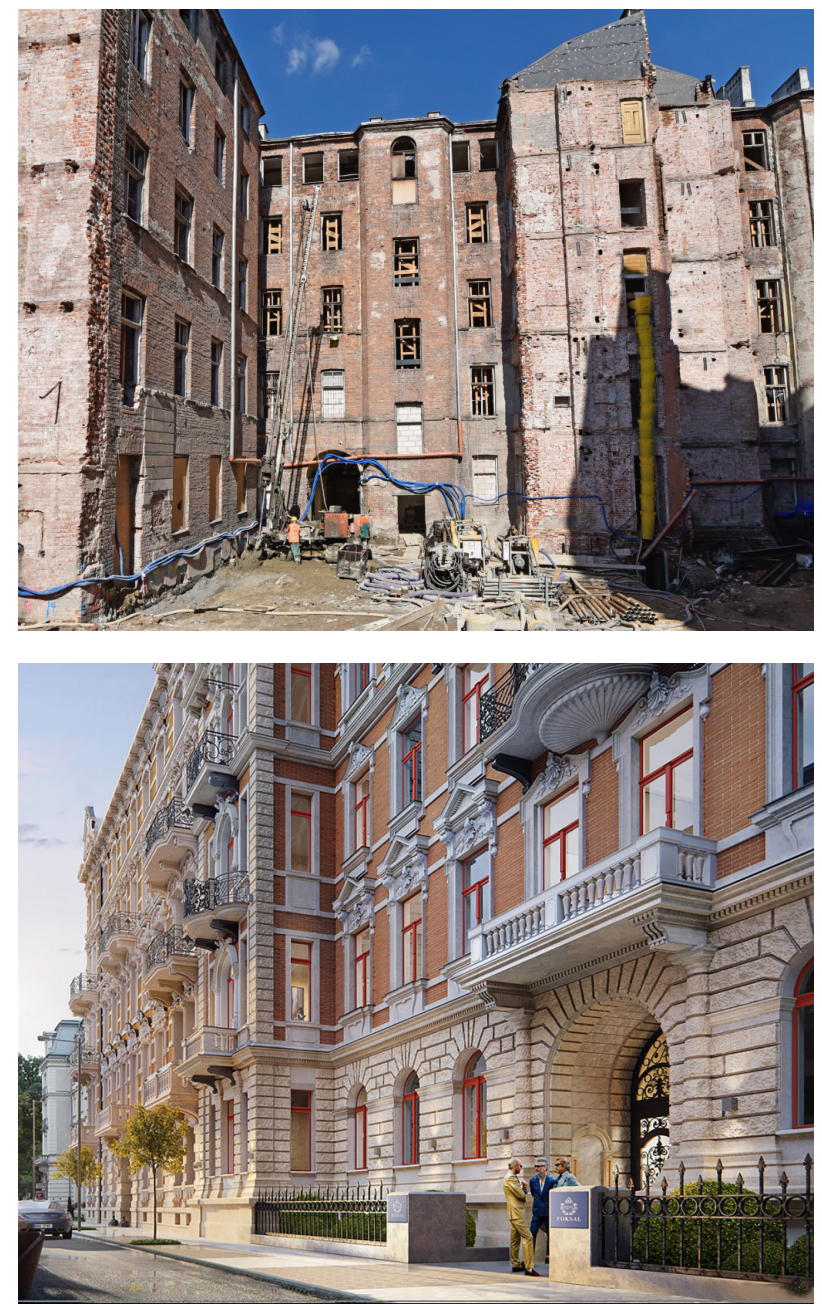

Figure 1. Historical building Foksal 13 before (top) and after (bottom) reconstruction.

rain. In a supplementary survey, water-filled sanded lenses were found at depths of about $4-5 \mathrm{~m}$ below the terrain. 


\section{Design Solutions of Underground CONSTRUCTIONS}

\subsection{Shoring of the Construction Pit}

In order to build an underground garage, it was first necessary to demolish two original court wings. The investor's endeavour was naturally to increase the scope for future garages.

Maximum excavation for newly built garages is 8.7$11 \mathrm{~m}$ below the existing terrain. The perimeter of the building pit is $140 \mathrm{~m}$, of which $110 \mathrm{~m}$ is secured by two rows of jet grouting $\varnothing 1000 \mathrm{~mm}$ with reinforcement pipes $\varnothing 108 / 12$. The remaining $30 \mathrm{~m}$ of the construction pit is secured by a microrider bracing made of profiles HEB 160.

All shoring walls were shotcreted with concrete of thickness $10-25 \mathrm{~cm}$, secured with nail length of 4.5 $7.5 \mathrm{~m}$ at $2-4$ levels. Shotcrete was performed from the maximum excavation level to $1 \mathrm{~m}$ below existing terrain. At a level of $-3.2 \mathrm{~m}$ the pit is secured by a steel frame consisting of struts and horizontal beams. Struts had lengths up to $19 \mathrm{~m}$. Horizontal beams along the whole construction pit was made of steel profiles $2 \times$ IPE 330 to $2 \times$ IPE 400 . It created a solid and stiff element that prevented the movement of the perimeter walls towards the building pit. Struts were designed from HEB 200 and HEB 300 profiles. The longest struts were designed from a pair of sheetpiles L604. Some of the struts passed through the micropile foundation.

In the area of a $30 \mathrm{~m}$ long microrider bracing, the steel frame emplaced at three levels, since no anchor elements could be used beyond the investor's own land. The pit is captured in Figure 2 while its technical scheme including all the designed solutions is shown in Figure 3

\subsection{Increasing the Bearing Capacity of Existing Foundations}

The reconstructed apartment buildings Foksal 13 and 15 have been given a complete replacement of the original wooden ceilings and now all the ceilings are made of concrete. The number of floors is also increased. This resulted in an increased load. At the same time floors in the cellars were deepened. Therefore, it was necessary to design appropriate special foundation elements to take account of these changed conditions [? ]. Probably the only acceptable option was the use of jet grouting technology. For this purpose, columns with diameter $1000 \mathrm{~mm}$ were designed at a spacing of $1.2-2 \mathrm{~m}$. The space between the columns was then filled with shotcrete.

In existing cellars, floor-to-ceiling heights range from $1.45 \mathrm{~m}$ to $2.1 \mathrm{~m}$ and the depth of foundation walls are below the existing floor level of $5-15 \mathrm{~cm}$. Excavations in the cellars increased by an average of $1 \mathrm{~m}$ and in some places where the engineering networks were designed, excavation was up to $1.8 \mathrm{~m}$. The greater extent of the excavations had an impact on the lengths of the jet grouting pillars as the pillars were partially exposed during excavations. Finally, the lengths of the TI columns ranged from 3 to $8 \mathrm{~m}$.

The columns of jet grouting were made from the ground floor (see Figure 4), which was partly under the protection of a heritage conservation institution. In the original design of demolition, all non-load-bearing walls on the ground floor were to be demolished. Based on this assumption, the starting points for drilling jet grouting were determined. However, after a renegotiation between the investor and the heritage conservation institution, changes were made and part of the non-bearing walls had to be preserved. In addition, there was a strict ban on doing any damage to the existing stairways, which were lined with marble. This resulted in a major redesign of starting points for the jet grouting columns.

The cellars of neighbouring buildings have been recently refurbished and are now used as a luxury restaurant (on the west side - Foksal 17) and warehouses (on the eastern side - Foksal 11). Due to the fact that the floors of adjoining cellars were at the same level and even deeper than the cellars of the reconstructed buildings, special constructions had to be designed along the boundaries of these buildings.

At Foksal 11, where the basement floor was below the existing cellar floor in Foksal 13, the technology was changed. Instead of the jet grouting, which would certainly damage the neighbouring basement areas, micropiles in combination with concrete beams were designed. This was done by sections and at one time only one meter of wall was under-excavated. This procedure was performed before excavations in the cellars. On the west side, the reconstructed Foksal 15 building and the adjacent Foksal 17 building had a common supporting wall. Jet grouting columns reinforced with a $108 / 12 \mathrm{~mm}$ tube were designed to take the vertical load and used as a shoring construction. However, before jet grouting columns were executed, a concrete beam of $1 \mathrm{~m}$ height was made, which allowed the head of the jet grouting columns to be $90 \mathrm{~cm}$ below the floor of the adjacent building.

\subsection{Micropile Underpinning of Existing MASONRY WALLS}

Part of the floor plan of the apartment buildings was located above the newly built underground garages, so it was necessary to underpin these parts. In the original technical solution, all walls were underpinned by massive jet grouting columns, and concrete walls were designed to be beside the jet grouting columns [? 1. However, this solution was space-intensive and greatly reduced the actual utility of the underground garage.

Therefore, another solution has been chosen. Micropile towers were designed to support the structures in question. The system was made of vertical steel pile pins of $108 / 16 \mathrm{~mm}$ in combination with a carrier steel grid of HEB beams 200 to $300 \mathrm{~mm}$. Micropiles 


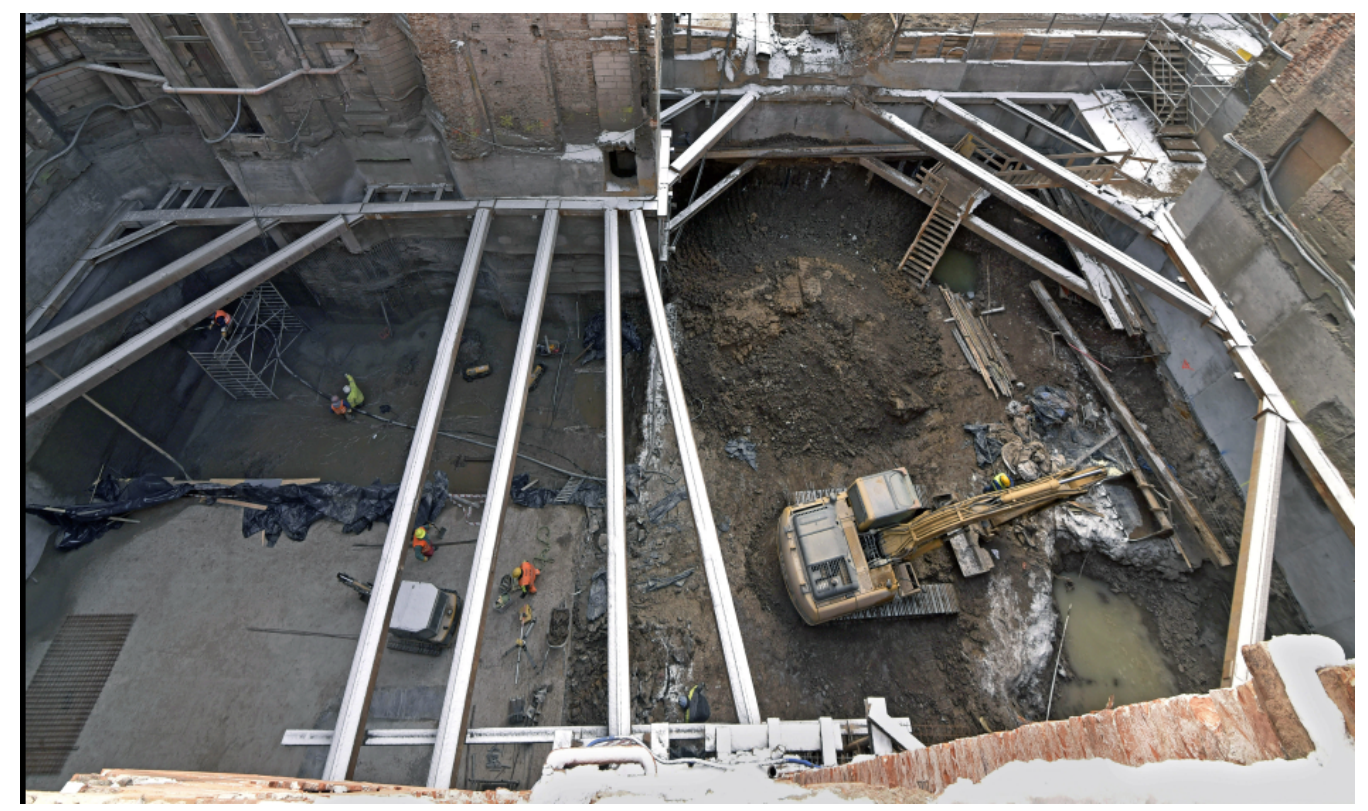

FIGURE 2. Construction pit - blinding concrete in process.

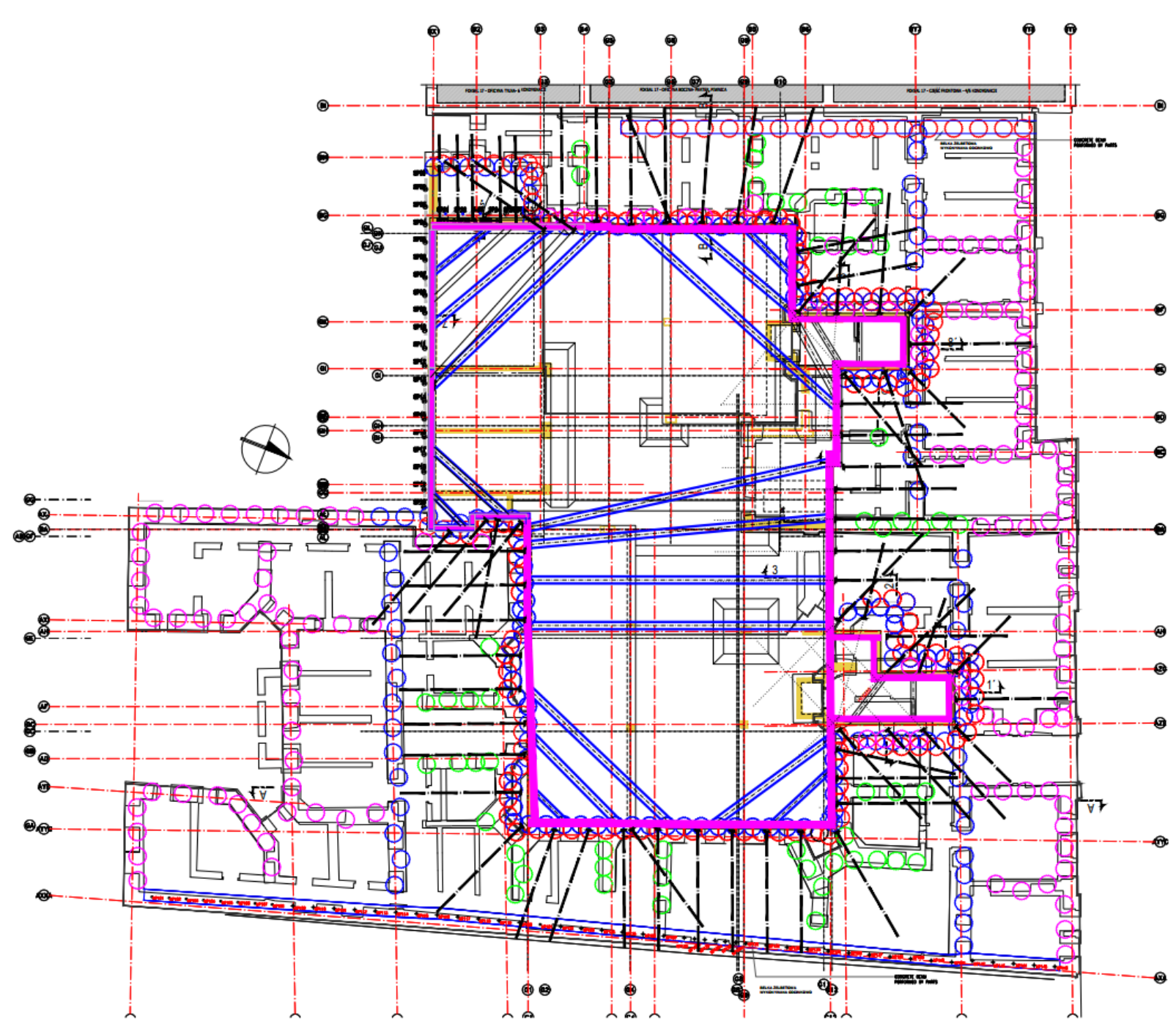

Figure 3. Layout - all the designed construction in one drawing. 


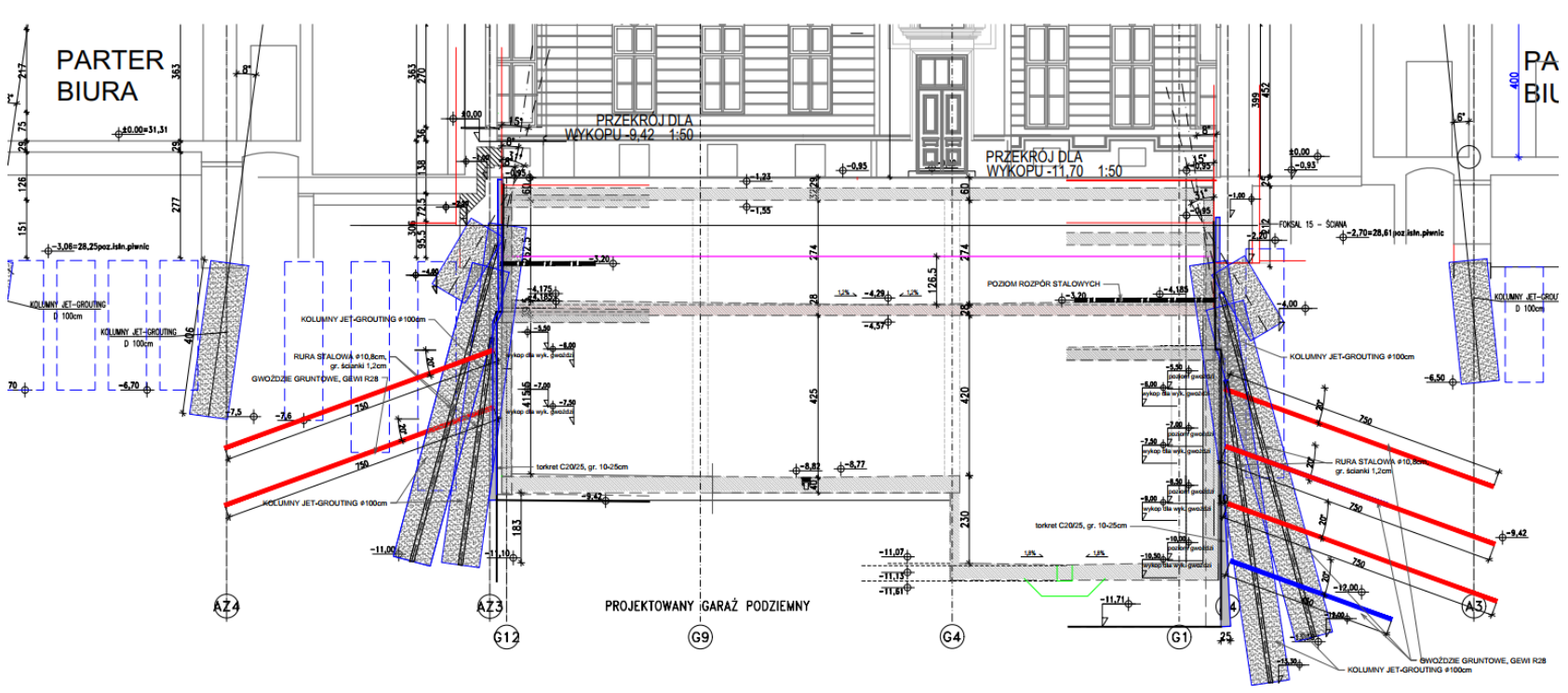

Figure 4. Cross section of the underground part of the building.

were braced between each other, both vertically and horizontally.

In the first stage, the micropiles were made from the existing yard terrain on one side of the cast wall and from the side of the basement of the building. Complications were brought by drilling of micropiles just from the basement, where the spatial conditions were very tight. Due to the low height of the ceiling micropiles had to consist of pieces with lengths of 1.0 and $2.0 \mathrm{~m}$. All micropiles were inserted into boreholes $\varnothing 160 \mathrm{~mm}$, filled with cement grouting. Underneath the level of the future definitive excavation of the garages, injected micropile roots in lengths of 6.0 $8.0 \mathrm{~m}$ according to load were made.

In the second phase, the micropiles were fitted with steel heads and the distribution grid was proceeded with. The distribution grid was designed above the future ceiling of the $1^{\text {st }}$ underground floor of the new building. The reason for this was the simple connection of the ceiling to the supporting wall. First, holes were made in the masonry to accommodate the steel cross members. Then the whole steel grid was thoroughly welded. In the end, the wall perforations were filled with concrete, thereby bringing into contact the steel grid and the masonry.

The third phase consisted of micropiles bracing in both directions. Individual phases are indicated in Figure 5

All phases in the implementation of micropile underpinning have been elaborated. All cross-sections were designed (each with bracing). The step of excavation, which could be done without bracing, was $1.5-2.0 \mathrm{~m}$. Bracing had to be adapted for passing steel struts through the micropile towers.

After the foundation slab was concreted, the process of building walls and removing bracing was begun. In total, 40 micropiles with a total length of $760 \mathrm{~m}$ were made. The layout of micropile underpinning is shown in Figure 6 .

Polish engineers attested to the fact that this was the first time micropile underpinning was used in Warsaw.

\subsection{Monitoring}

With regard to the proposed design for deep excavations creating an underground garage, a monitoring project was prepared prior to the construction work. A network of control points for geodetic measurement was set up for Foksal 13 and Foksal 15. Some points were placed on adjacent buildings, and in total 52 measuring points were created. The frequency of measurement was adapted to the working tempo and rate of execution of the substructure. The measurement results are analyzed continuously by the building management, the research authors and include investor presence. The following tolerances have been adopted for existing buildings:

$$
\begin{aligned}
& {\left[\mathrm{s}_{\mathrm{k}}\right]_{\mathrm{u}}=5-7 \mathrm{~mm},} \\
& {\left[\mathrm{~s}_{\mathrm{k}}\right]_{\mathrm{n}}=15-18 \mathrm{~mm},}
\end{aligned}
$$

$\left[\mathrm{s}_{\mathrm{k}}\right]_{\mathrm{u}}$ - maximal vertical displacement for serviceability limit state (SLS),

$\left[\mathrm{S}_{\mathrm{k}}\right]_{\mathrm{n}}$ - maximal vertical displacement for ultimate limit state (ULS).

The results of the monitoring showed that the recorded measurements were within the tolerances throughout the construction, which indirectly confirms the correctness of the design of the technologies involved and the construction of the special foundation.

\section{Conclusion}

The underground garage project on Foksal 13 and 15 was a very interesting task from a design perspective. Unfortunately, it was difficult to meet the changing 

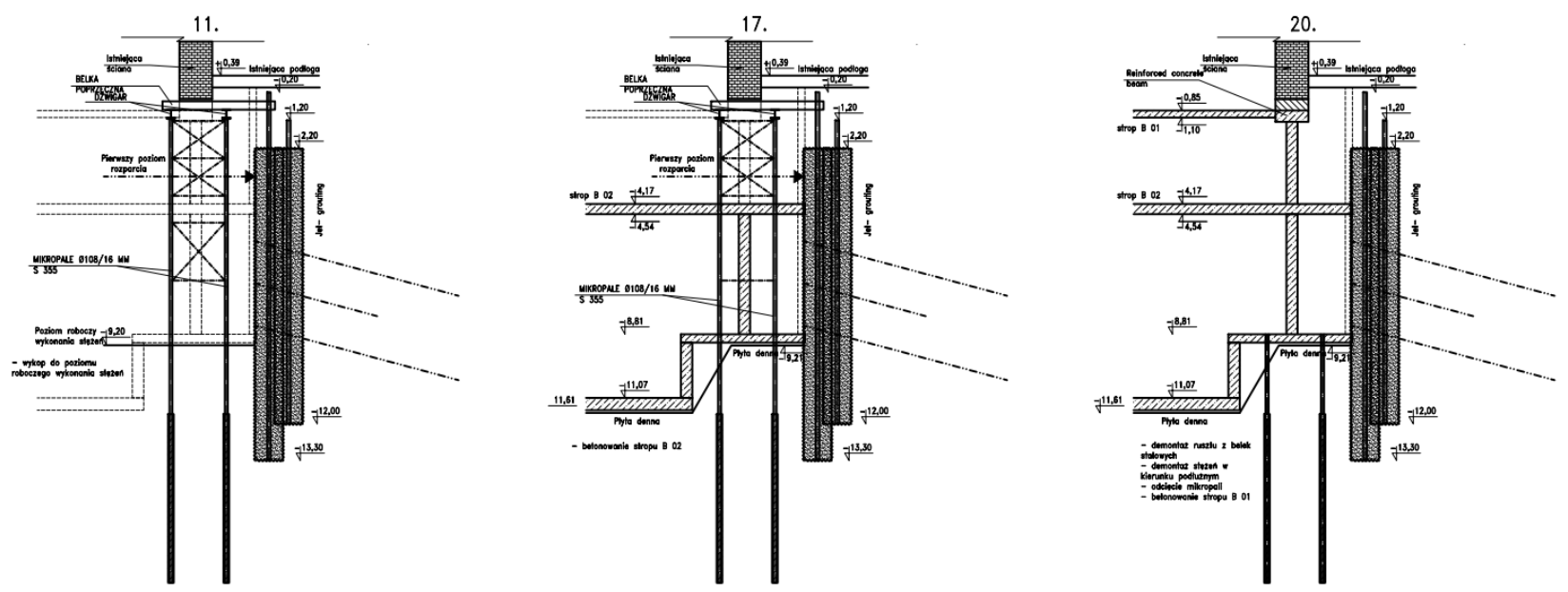

FigURE 5. Cross section of micropile underpinning - selected phases.

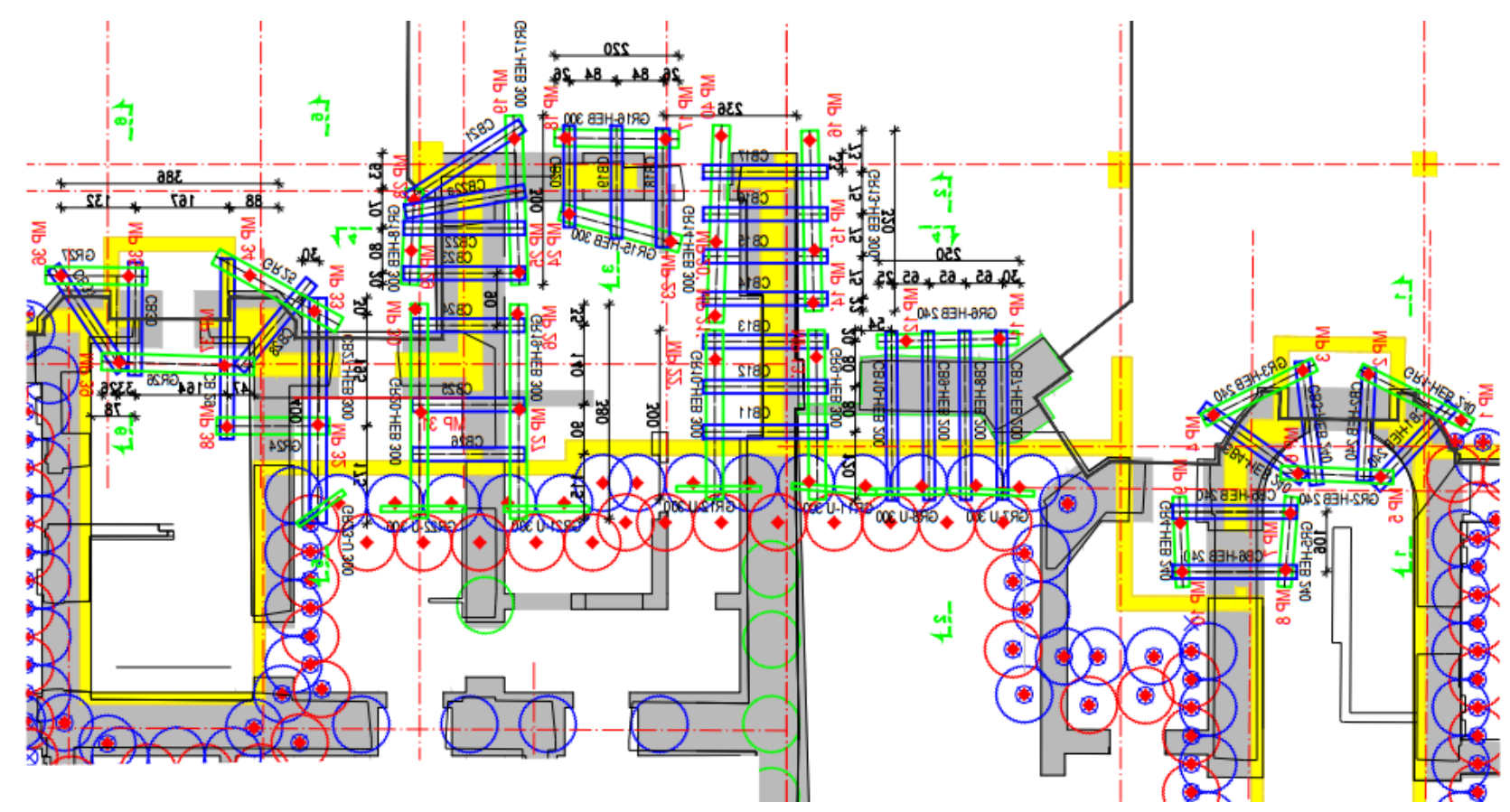

FiguRE 6. Layout of micropile underpinning.

requirements of the investor and the chief designer. In addition, the language barrier did not do much to facilitate the project. The project was prepared in Czech and English with minor changes being made in Polish. However, all the difficult situations that emerged have been positively addressed by intensive communication with the investor and the management of the building. Proof of this is that the underground garage construction is now successfully completed.

\section{REFERENCES}

[1] K. Terzaghi, R. Peck. Soil Mechanics in Engineering Practice. Second edition. Wiley \& Sons Inc, New York, 1967.

[2] J. Lehtonen, V.-V. Hyyppä. Classification of Micropile Underpinning Methods Exemplified by Projects in

Turku. Electronic Journal of Geotechnical Engineering 15:295-310, 2010. 